\title{
A Reflection on the Samuelson-Garegnani Debate
}

\author{
Ajit Sinha, Azim Premji University, Bangalore, India \\ sinha a99@yahoo.com
}

\begin{abstract}
This paper argues that Samuelson's criticisms of Sraffa mainly concentrated on Sraffa's claim that the propositions of his book (Sraffa 1960) did not depend on the assumption of constant returns to scale. Garegnani's defence of Sraffa against Samuelson's criticisms remained ineffective because Garegnani's own interpretation of Sraffa's prices as classical 'centre of gravitation' or 'long term' prices requires constant returns to scale assumption. The paper goes on to critique Garegnani's interpretation of Sraffa and the classical economics to show that Garegnani's interpretation of Sraffa and the classical economics is highly problematic and that Samuelson's criticism of Sraffa does not hit the target because Sraffa's prices are not necessarily 'equilibrium' prices and therefore there is no need of returns to scale assumption in his theory.
\end{abstract}

Keywords: classical economics, constant returns to scale, Garegnani, Samuelson, Sraffa, standard commodity

\section{Introduction}

Sraffa's book (1960), Production of Commodities by Means of Commodities, is perhaps the most enigmatic theoretical work ever published in economic theory. Of course, all classics are somewhat puzzling and do give rise to a number of interpretations over a period of time. But Sraffa's book is special in this respect. Upon its publication, many contemporaries of Sraffa hailed it as a definite classic but at the same time acknowledged their inability to completely understand what the book was all about (e.g., Harrod, 1961). And Sraffa's complete silence on explicating its terse prose was of no help. Its destructive potential for orthodox economics, however, came to the fore in the famous capital theory debates between the two Cambridges' in the 1960s (see Harcourt, 1969), when one of the leaders of the orthodoxy, Paul Samuelson (see 'Symposium 1966'), admitted that Sraffa's proposition about 'reswitching of techniques' proves that the orthodox parable regarding 'quantity of homogeneous capital' is wrong. Pierangelo Garegnani (see 'Symposium 1966') was one of the participants on the winning side of this debate. Soon after, however, the orthodoxy came to the conclusion that the destructive potential of Sraffa's book could be confined to this simplified 'parable' only, and that the more sophisticated general equilibrium theory, which does not need the notion of aggregate quantity of capital prior to price determination, remains unscathed. Frank Hahn $(1975,1982)$ further argued that Sraffa's book can be interpreted as a special case of inter-temporal general equilibrium, and so the orthodoxy need worry about it no more.

This notwithstanding, Paul Samuelson was perhaps the only leading orthodox economist who maintained a sustained critical interest in Sraffa's slim volume until the end of his life (Samuelson died in December 2009) and Pierangelo Garegnani (who passed away in October 2011) was always willing to engage Samuelson in debating all matters Sraffian. This included not only the matters that directly pertained to Sraffa's book but also the 'Sraffian' interpretation of classical economics, championed by Garegnani himself. The recent 
publication of some of the major exchanges between these two luminaries of their respective schools of thought under one cover (see Kurz, 2013) has given an occasion for me to reflect on this debate and hopefully raise some questions for further consideration.

Samuelson (2000) in his paper, 'Sraffa's hits and misses', specifically makes three criticisms of Sraffa (1960): (i) Sraffa's claim that he does not make any assumption regarding returns to scale is not true, (ii) the Standard commodity is a useless device, and (iii) the limitations of land and capital are underplayed in his theory.

\section{On the Assumption Regarding Returns to Scale}

On point (i), Samuelson's main attack focuses on Sraffa's example of the 'subsistence economy' in his Chapter 1. Samuelson argues that Sraffa's example of the 'subsistence' economy given by:

280 qr. wheat +12 t. iron $\rightarrow 400$ qr. wheat

120 gr. wheat +8 t. iron $\rightarrow 20$ t. iron

necessarily assumes constant returns. Why? Because, according to Samuelson, Sraffa's snapshot of this economy is in self-replacing state at the given scale of production, but this snapshot position must have been arrived at by the Darwinian competitive process that entails adjustment of the quantities produced. Therefore, it cannot be claimed that the system would arrive at such a position by the mechanism of quantity adjustment without the assumption of constant returns. For example, Samuelson argues that suppose Sraffa's snapshot of the economy revealed a disequilibrium position such as:

$$
\begin{aligned}
& 350 \text { wheat }+15 \text { iron } \rightarrow 500 \text { wheat } \\
& 90 \text { wheat }+6 \text { iron } \rightarrow 15 \text { iron. }
\end{aligned}
$$

In this case, we have excess supply of wheat and excess demand for iron. Now the wheat industry would contract and the iron industry would expand to a self-replacing subsistence system, only if constant returns were assumed. Actually, Sraffa in his sole footnote of Chapter 1 specifically states that for a system of this type, i.e., a subsistence system, such adjustment must be possible. Samuelson partially quotes this footnote and goes on to add: 'Oops! Only in constant returns to scale technologies do proportions matter and alone matter! Otherwise scale and proportions interact to deny the quoted claim' (Samuelson in Kurz, 2013, pp. 18-19).

What is Garegnani's response to all this? Before we get to that let us look at the full quotation from Sraffa's (1960) footnote of Chapter 1 that is under contention:

'This formulation presupposes the system's being in a self-replacing state; but every system of the type under consideration is capable of being brought to such a state merely by changing the proportions in which the individual equations enter it. (Systems which do so with a surplus are discussed in $\S 4 \mathrm{ff}$. Systems which are incapable of doing so under any proportions and show a deficit in the production of some commodities over consumption even if none has a surplus do not represent viable economic systems and are not considered)' (Sraffa, 1960, p. 5). 
Garegnani's (2007a) response is that Samuelson confuses Sraffa's argument about abstract mathematical operations on equations with changes in the real system itself: '... That of course is true, but it applies to proportions between actual outputs and not to proportions between equations, as Sraffa is careful to specify in the one word we italicised in this passage' (Garegnani in Kurz, 2013, p. 58, Garegnani's emphasis). This I find highly unsatisfactory. Sraffa clearly states that 'every system of the type under consideration is capable of being brought to such a state.... Hence the reference is to the 'system', which is capable of being brought to such a state, and not simply a mathematical operation on equations.

So let us go back to Samuelson's disequilibrium example. Even when the system is in disequilibrium, if it is a subsistence system then the price ratio between the two industries are still well established. This is because it is a definitional property of a subsistence system that the values of each industry's inputs must be equal to the values of its output, i.e., no industry produces any surplus or deficit. This property establishes the exchange ratio between the two industries as 1 ton of iron for 10 quarters of wheat. Given this exchange ratio, it is clear that the iron industry is capable of reproducing itself by selling 9 tons of iron for 90 quarters of wheat. But then the wheat industry is left with 9 tons of iron and 410 quarters of wheat. But it can combine 9 tons of iron only with 210 quarters of wheat and thus 200 quarters of wheat must go to waste. Thus the inputs of the wheat industry contract by $3 / 5$ times. Now it is clear that this system will be again in a self-replacing state if the output of the wheat industry turns out to be 300 quarters of wheat, i.e., the industry displays constant returns to scale. What if the wheat industry is characterised by diminishing returns to scale? In this case, the system will cease to be a 'subsistence system' and turn into a 'surplus system' with a surplus of wheat output. Similarly, if increasing returns prevail then the system would turn into a deficit system. Sraffa, in his parenthetical note, states that he deals with such surplus systems in $\S 4 \mathrm{ff}$. and does not discuss the deficit system because it does not have historical viability. Thus it is clear that it is a mathematical property of a subsistence system, i.e. 'the system of the type under consideration' that must be characterised by constant returns to scale, otherwise slight vibration in the system would convert it into either a surplus or a deficit system. This, however, does not mean that the system producing surplus must also display constant returns, as it is clear that if the wheat industry displays diminishing returns then the system turns into a surplus system, a type that Sraffa discusses in §4ff. Hence Samuelson's choice of the example of a 'subsistence system' for an attack on Sraffa's claim that he makes 'no assumptions regarding returns to scale' was misplaced (see Sinha, 2007 for a more detailed response to Samuelson on this point).

Garegnani's response to Samuelson on this point, however, is a non sequitur. My interpretation gets further support from a draft of the footnote written by Sraffa in March 1956:

Note to p. 4. 'The statement in this form applies only to a system which is in a self-replacing state. But any system, to be consistent, must be capable of being brought to such a state merely by changing the proportions in which the several equations enter it. If this is not possible there may be a deficit or a surplus, but no equality' (Sraffa-Papers D3/12/71: 5).

Now, what could the phrase, 'If this is not possible', mean? If Garegnani's interpretation was correct then the question of it being not possible does not arise - such mathematical operations on the equations must always be possible. But Sraffa's point is that the system may not revert back to a subsistence system if the industries were not characterised by constant returns. 
But what about the system that produces a surplus? Samuelson interprets Sraffa's surplus system to be in a steady or a stationary state. This is because of two reasons: (a) Sraffa's surplus system is characterised by a uniform rate of profits across industries; hence his system is assumed to be in equilibrium and (b) the prices of both the inputs and outputs are the same in his equations. Again, this does not sit well with the evidence in Sraffa's book. A stationary state, in the classical sense, prevails when the rate of profits in the system reaches its minimum or when it is assumed that all 'surplus' is consumed by the capitalist class. Now, Sraffa consistently works out the movements of prices when the rate of profits is increased from the notional zero per cent to its maximum possible value. Furthermore, nowhere in the book does Sraffa assume that all the surplus is consumed by the capitalists. Thus this rules out a stationary state assumption. As far as steady state is concerned, it implies a constant returns assumption, which is denied by Sraffa. Furthermore, a steady state requires that employment of labour must rise at the same rate as capital is accumulating. This requires either a compatible theory of labour supply (e.g., a compatible theory of population) or an assumption of unlimited labour supply at the given wages - neither are even mentioned in Sraffa's book.

Garegnani, however, does not specifically dispute that Sraffa's system is in equilibrium, but argues that his 'equilibrium' is of a different nature than the case of either the steady state or the stationary state. Here Garegnani introduces his own reading of classical economics, which is not present in Sraffa's book, and interprets Sraffa's system to be implicitly following such a reasoning. In a nutshell, Garegnani's argument is that there is a 'core' of classical theory, which is designed to determine prices and the rate of profits in a surplus producing system (also see Garegnani 1984, 1987, 1990a). This core is characterised by three given variables: (i) total gross outputs or 'social product', (ii) technique of production or 'techniques' and (iii) 'real wage'. The 'social product' and 'techniques' together are supposed to determine the 'labour employed' and the 'labour employed' along with the 'real wages' determine 'necessary consumption'. Now 'social product' minus 'necessary consumption' determines 'surplus - share other than wages'. Given all this, the 'core' of the theory is supposed to determine the prices and the rate of profits in this system.

According to Garegnani, the core of the theory can be formulated in mathematical terms and precise answers to the determination of prices and the rate of profits could be found. However, as far as the determinations of the givens of the core, i.e., the 'social product', 'techniques' and 'real wages', are concerned, they are determined in a broad sociohistorical context, which cannot be formulated in precise mathematical terms and so is also the case with the rebound effect of these variables on each other:

'On the one hand, we have the necessary quantitative relations, which competition entails between commodity prices and distributive variables and, which, in their comparative simplicity, are of a nature allowing for a mainly deductive treatment. On the other, we have the circumstances determining what we have described as the 'intermediate data': the subsistence or, more generally, the wage, the outputs, the technical conditions of production. These circumstances were seen to be closely related to institutional and historical factors, which, because of their complexity and variability according to circumstances, prevented deducing the corresponding variables from a few basic principles as was possible for prices and profits in the "core"' (Garegnani, in Kurz, 2013, p. 52). 
Let us now look at the nature of Garegnani's 'givens' carefully. Let us first take the given 'social product'. Is this an observed gross output vector after a production cycle is over? Garegnani's answer is, no:

'... no economist had previously supposed the economy to ever actually be in equilibrium position, or more generally in a position of rest, except by fluke: gravitation around such positions and not achievement of them being what was always thought relevant for the positions of the economy in the focus of the analysis' (Garegnani, 2012, pp. 1429-30, emphasis in original).

By 'given social product' Garegnani means a vector of physical outputs that corresponds to a supposedly known vector of 'effectual demands'. This is because, according to Garegnani, the prices that the classical economists determine are the 'long-term' equilibrium prices - in the sense that these prices would hold only when the set of outputs adjusts to a given set of 'effectual demands'. Garegnani distinguishes this notion of equilibrium from the equilibrium arrived at by the simultaneous interaction of the supply and demand functions of the neoclassical variety. In the classical case, according to Garegnani, what is known is the set of 'effectual demands', i.e., the demand points and not demand functions and the given output is assumed to be equal to those given demand points. But if the given demand points are points in price-quantity space, then those demand points must also represent a set of prices, which is how 'effectual demand' is defined by Adam Smith. So the problem of solving for 'long-term' prices simply does not arise, since they must also be known along with the known 'effectual demands'. As Garegnani himself admits:

'The second difference is that the natural price-corresponding to an equilibrium price in modern terms_far from being an unknown to be determined by those 'supply and demand' as in neoclassical theory-is there a given for the very definition of the demand, the single quantity' (Garegnani in Kurz, 2013, p. 55, original emphasis).

In Adam Smith's (1981 [1776]) case, however, these demand points are not known data. His claim is that at any given moment a given set of outputs would be associated with a set of effectual demands, and if the output set is not equal, one-to-one, with its associated effectual demand set then a gravitation mechanism comes into play which adjusts supplies to the given set of effectual demands and the prices that represent those demand points can be discovered by knowing the natural rates of wages, profits and rent. The argument implicitly assumes a linear technique or constant returns with no possibility of substitution between factors (see Sinha, 2010a; c for details).

Garegnani, on the other hand, needs to know the effectual demand points because he needs to write the production equations such that its outputs are exactly equal to the effectual demands - so that no adjustment in outputs is required and thus no assumption, regarding returns to scale, is needed. Garegnani foists such an interpretation on classical economics in order to bring it in line with Sraffa's equation system, which, as Sraffa claims, does not make any assumption regarding returns to scale:

However, as we shall see, a separate determination of outputs is possible and was in fact associated with the different classical theory of distribution considered above-and this is precisely what underlies Sraffa's assumption 
of given outputs and the independence of his analysis from constant returns to scale (Garegnani, 1990a, p. 129, emphasis in original).

An implication of this, however, turns out to be that the main problem of the theory becomes redundant. To avoid this, Garegnani reinterprets the classical notion of 'effectual demand' as a vertical straight line in quantity-price space: '... naturally leads ... to a determination of outputs also independent of any such functions and, accordingly, separate from that of prices...' (Garegnani in Kurz, 2013, p. 51, emphasis added). In this case, the determination of the equilibrium price would require the solution of the 'given output' equations. But this reinterpretation of the classical notion of 'effectual demand' rules out the possibility of any classical gravitation mechanism, of which Garegnani himself makes so much. If the 'effectual demand' is a vertical straight line in quantity-price space, then any shortfall (given the 'effectual demand') in the quantity supplied in the market must lead to 'market price' rising to infinity, and in the converse case 'market price' falling to zero. If 'market prices' are supposed to be actual prices at which commodities do exchange in the market (when the system is not in equilibrium) then the rationing function of the rise in prices on quantity demanded cannot be denied.

The problem with Garegnani's reasoning becomes evident once we interrogate the grounds on which Garegnani claims that the vector of 'effectual demands' is known:

'These will be, to begin with: (1) the level of aggregate income and activity; (2) the technical conditions of production (governing, among other things, the outputs of means of production); (3) the distribution of the social product among the social classes (and therefore, in terms of the classical theories, the level of the independent distributive variable), since different classes generally spend their income on different commodities' (Garegnani, 1990a, p. 129).

It is, however, clear that all the three items in Garegnani's list can be known only if we know the vector of gross outputs produced. Otherwise, what does it mean to know the level of aggregate income and activity'? Similarly, how can one know what would be the total demand for the commodities that function as inputs, unless we know what has been the total utilisation of inputs in the system and the savings decisions of the capitalists (assuming workers don't save)? Moreover, the levels of aggregate incomes of either the workers or the capitalists cannot be known unless the vector of outputs is known. In other words, Garegnani's argument runs in a circle: the vector of outputs is supposed to be equal to the vector of effectual demands, which in turn is supposed to depend on the vector of outputs!

Garegnani, however, has another explanation of the idea of 'given output'. In this explanation the 'given output' is supposed to be the average of several years of actual outputs, which is considered to be the long-period equilibrium output, towards which the actual outputs are supposed to be adjusting or gravitating to: '... (the actual magnitude corresponding to it [Sraffa's system], would, if anything, be a moving average calculated over several years)' (Garegnani, 1990b, p. 350, emphasis in original). Garegnani determines this to be the feature that distinguishes the classical equilibrium from the steady or stationary state positions. He argues that the steady or stationary state equilibriums do not allow any adjustment for the empirical system, whereas the 'long-term' equilibrium notion allows 'the possibility of a correspondence between theoretical and observable variables' (Garegnani in Kurz, 2013, p. 81). Here the 'theoretical' long-term position is acknowledged to be an 'ideal' and not an actual or 'empirical' position: 
'The "normal position" may be taken as a typical instance of Pareto's "ideal phenomena" in economics, centred as it is on Adam Smith's "central price", to which "the prices of all commodities are continually gravitating" (1776, I: 51) and therefore providing what Pareto calls here a "general or average fact"' (Garegnani, 1990b, p. 95, n. 72).

Nevertheless, the problem remains. If the ideal outputs are the average of several years of past outputs, then what are the inputs that go along with those outputs in the equations? If they are also the averages of the past years of inputs, then this amounts to assuming constant returns for the industries. The distance between Garegnani's interpretation of Sraffa's equations and Sraffa's own position becomes apparent when one juxtaposes Garegnani's above statement with Sraffa's characterisation of his equations as 'the actual economic system of observation' (Sraffa, 1960, p. 22, emphasis added) or as '[a] year's operations can be tabulated as follows ...' (Sraffa, 1960, p. 3, emphasis added). These statements clearly refer to particular empirical data rather than 'general or average fact'.

Now, let us take the second item on the list of givens, viz. the 'techniques'. Garegnani nowhere explains what he means by the term 'techniques'. Are they production functions, which specify all the levels of outputs that would be produced with changes in inputs, or are they simply an observed set of inputs utilised to produce the observed set of outputs? The former case implies some assumption regarding returns to scale, e.g., Leontief technique with constant returns implicit in it; whereas the latter case is a one-point observation (such as Sraffa's 'actual economic system of observation') and cannot predict how outputs would behave with changes in inputs. Since Garegnani accepts that, most likely, the observed inputoutput data will not be in the classical centre of gravitation, the problem with the 'given output' position turns out to be this: even if we know what the output set must be, we still have no way of knowing what the input set must go along with that output set, unless we know the production function.

We now take up 'real wages', the last item of Garegnani's 'givens'. Unless we assume homogeneous labour throughout the economy and minimum subsistence wages, the idea of given 'real wages' remains quite vague. First, assume labour to be homogenous. In that case, if wages are higher than the minimum subsistence, then it is quite plausible that the wage baskets of different workers would reflect their individual tastes, so what meaning could be given to the 'given real wage'? Now, if labour is not homogeneous then how do we reduce a goldsmith's wage to an ironsmith's wage and down to a bricklayer's wage? What kind of comparison could one make in real terms? The classical economists proposed to reduce heterogeneous labour to homogeneous labour by using the given wage differentials as the reduction factor. But these wage differentials make sense only in terms of 'money wages' and not in terms of 'real wages'. Thus the total labour employment, in the sense of total homogeneous labour-time employed in the system, depends on the total wage bill of the system.

Now, to cut through this Gordian Knot, we must take the vectors of inputs and outputs as observed data after a production cycle. But then, according to Garegnani, such an observed data would, most likely, not be equal to the set of 'effectual demands' and thus prices associated with the observed system will not be equal to the 'long-term' classical equilibrium prices, which are characterised by the uniform industrial rate of profits. Thus the only way to reconcile the idea of the 'long-term' classical equilibrium prices with Sraffa's equations is to ascribe linear techniques to Sraffa's equations. But of course, Sraffa emphatically denied making such an assumption. 
But how could Garegnani go wrong on such a straight forward theoretical issue? As a matter of fact, in his Ph.D. dissertation, which was completed in 1958, Garegnani explicitly admitted that the classical economists assumed constant returns:

'We can here remember that Smith and Ricardo's theory of price is founded on the assumption of constant returns to scale for manufactures, while the position of the margin in agriculture is given since it is treated as broadly determined by the level of accumulation and population' (Garegnani, 1959, p. 29, f.n. 2, emphasis added).

Obviously, at this stage Garegnani did not know Sraffa (1960). It was only after 1960 that Garegnani found it necessary to expunge the constant returns to scale assumption from classical economics to bring it in line with Sraffa (1960). But the task proved to be akin to squaring a circle.

Instead of directly interpreting classical economics - particularly the gravitation mechanism - and discovering the underlying constant returns assumption in it, as he had done in his Ph.D. dissertation, Garegnani now chose to analyse the significance of the returns to scale assumption in modern economics. He argued that the returns to scale assumption is linked with price determination in modern economic theory, due to its particular theory of income distribution. In modern economic theory, wages and the rate of profits are determined simultaneously with prices and if an economy is not in steady-state equilibrium then changes in the scale of production would affect the demands for factors and hence change the factor prices or income distribution, which in its turn affect the technique chosen and the cost of production of commodities. Garegnani argues that the assumption of wages given from outside, and independent of the scale of production in classical economics, takes away the main role of returns to scale in the theory of prices and therefore it is not needed by the classical theory.

Though it is true that the assumption of 'given wages' takes away the impact of changes in wages and the technique on prices, it is clearly not the whole story regarding the returns to scale assumption. The returns to scale assumption is mainly an assumption regarding the 'given technique', i.e., how physical changes in inputs are related to physical changes in outputs. And, as Garegnani recognises, classical economists did discuss the question of variable returns in the context of economic growth - such as Ricardo's treatment of diminishing returns in agriculture and Smith's treatment of increasing returns in manufacturing. He, however, then goes on to notice the absence of variable returns in the classical treatment of the gravitation mechanism and concludes from there that the assumption of returns to scale, as such, is irrelevant to the classical theory of price determination:

'Let us in fact suppose for a moment the presence also in those classical authors of neoclassical-like demand functions for the products, and consider the two elements that could cause Marshallian returns to be variable and accordingly make those functions be relevant there also. The first such element is changes in factor prices functionally linked to changes in relative outputs. The exogenous wage eliminates that element with regard to the division between wages and non-wage shares of the product and, to that extent, allows for a determination of prices separate from outputs and independent of demand functions we have assumed. 
The second element is non-constant physical returns to proportional changes of labour and capital: i.e. either decreasing physical returns to scale because of the scarcity of land (affecting in Ricardo the division the product between rent on the one hand and profits plus wages on the other) or increasing physical returns because of an increase in the division of labour. However, Ricardo treated decreasing returns from land, just as Smith had treated the increasing returns from division of labour: as relevant, that is, only for the comparatively large output changes involved in capital accumulation and growth. Unlike what happens in neoclassical theory, Smith and Ricardo could therefore leave physical returns to scale quite naturally aside when dealing with relative prices in a given position of the economy, with the kind of comparatively small output changes generally involved in that specific analysis' (Garegnani in Kurz, 2013, pp. 52-53).

It is, however, elementary that the absence of variable returns does not imply an absence of the returns to scale assumption, as such, if there are changes in output - all it implies is a presence of constant returns to scale, an assumption Garegnani had well understood in his Ph.D. dissertation. It should also be noted that the 'comparatively small output changes' that Garegnani refers to above are the precise conditions for which the neo-classical supply functions are well defined - i.e., they are well defined only in the neighbourhood of the equilibrium point, e.g., any large change in output would clearly break the Marshallian assumption of ceteris paribus. Thus to suggest that returns to scale are irrelevant to 'small output changes,' is a red herring.

So, is Samuelson right in attributing this assumption to Sraffa? The answer is: no. Both Garegnani and Samuelson make the mistake of interpreting Sraffa's prices as 'equilibrium' prices. Sraffa, however, is quite clear that if the reader interprets his prices as 'equilibrium' prices then she will ascribe the constant returns assumption to his equations but he, as a matter of fact, does not make any such assumption, which implies that the interpretation of his prices as 'equilibrium' prices is not legitimate: 'Anyone accustomed to think in terms of the equilibrium of demand and supply may be inclined, on reading these pages, to suppose that the argument rests on a tacit assumption of constant returns in all industries. ... In fact, however, no such assumption is made' (Sraffa, 1960, p. v). As I have argued in various places (e.g., Sinha, 2010a; 2012; 2013; 2014; Sinha and Dupertuis 2009a; b), the condition of a uniform rate of profits in Sraffa's equations is not a reference to 'equilibrium condition' but rather it is a logical corollary of the assumption of uniform 'commodity-money' wages given from outside the equation system irrespective of the condition of 'equilibrium'. Since Sraffa's equations represent tabulation of observed inputs and outputs of an empirical system, it is completely independent of the notion of 'equilibrium' and 'change' and hence completely independent of the notion of returns to scale. Garegnani's attempt to insert the notion of equilibrium in Sraffa's equations, but at the same time not allow the notion of returns to scale in it, introduces a contradictory theoretical positioning that he naturally was never able to resolve, as is evidenced by his admittance of 'comparatively small output changes' contrasted against Sraffa's emphatic position that '[n]o changes in output and (at any rate in Parts I and II) no changes in proportions in which different means of production are used by an industry are considered' (Sraffa, 1960, p. v).

This brings us to a fundamental methodological difference between Garegnani's approach to economics and Sraffa's. Garegnani remained wedded to the methodology of mechanical causation, which gives rise to the ideas of 'forces of gravitation' and 'equilibrium'. Sraffa rejected mechanical causation on the grounds that one can never be certain about 
relations based on causation; e.g., the cost of production of wheat would be affected very differently if an increase in its demand came at the cost of a fall in the demand for rice or a fall in the demand for boots. In the first case (with a fall in the demand for rice) where no additional land needs to be brought under cultivation, no Ricardian diminishing returns would kick in; however, in the second case (with a fall in the demand for boots) most likely, the Ricardian diminishing returns on land would kick in as additional marginal land would need to be brought under cultivation. Thus a mathematical causal function - relating output to cost is not possible. This led Sraffa to reject counterfactual reasoning, which is at the heart of all functional relations. Sraffa on the other hand maintained that a geometrical theory, which eschews causation, can be developed in precise mathematical terms, if it relates variables that can be measured in quantitative terms. As Sraffa explains in one of his unpublished notes:

'The general confusion in all theories of value (except Marx probably) must be explained by the failure to distinguish between two entirely distinct types of questions and the universal attempt of solving them both by one single theory.

The two questions are:

1) What determines the [difference in the ?] values at which various commodities are exchanged in a given market on a given instant?

2) What determines the changes in the values of commodities at different times? (e.g. of one commodity) ...

The first problem gives rise to a geometrical theory, the second to a mechanical one' (Sraffa-Papers, D3/12/7: 115).

His famous equation, $r=R(1-w)$ is of a geometrical nature. It relates the rate of profits of any given empirical system, to the productivity of the system as a whole and the wages specified in terms of the Standard commodity. In this case, the relationship between the rate of profits and the wages in terms of the Standard commodity is of a similar nature to the relationship of one angle with the other two angles in any Euclidian triangle - given two angles the third angle can always be deduced precisely. In Sraffa's case, given any empirical system of inputs and outputs, its $R$ is determined independently of the values of $r$ and $w$, and so for any given value of $w, r$ of the system is precisely determined - or for any given value of $r, w$ of the system is precisely determined. But these relations hold only for the given data of inputs and outputs, they do not predict how $r$ would be affected in time $t+1$, if trade unions succeed in winning a rise in wages in time t. Answers to such questions require precise knowledge of relations between these variables in terms of causation. Sraffa's equations only tell us that in time $t+1$ we again get new inputs and outputs data, for which $r=R(1-w)$ must again hold.

\section{On the Irrelevancy of the Standard Commodity}

On point (ii), Samuelson argues that 'Ricardo's goal is the intertemporal and interspatial comparison of price vectors, which tries to separate out real and unreal changes' (Samuelson in Kurz, 2013, p. 24). This identifies Ricardo's problem with the index number problem. Within this context, Samuelson finds Ricardo's search for an 'invariable measure of value' ill-defined and Sraffa's Standard commodity to be of no help. He goes on to raise questions about the existence of basic goods and, therefore, the Standard commodity - both in single-product and 
joint-production cases. He seems to be quite lost about the purpose of the Standard commodity either in the case of Ricardo or Sraffa. And reacting to Sraffa's statement that 'Standard system is a purely auxiliary construction' (Sraffa, 1960, p. 31), Samuelson asks: 'Toward what is it an "auxiliary"?' (Samuelson in Kurz, 2013, p. 28).

Garegnani accepts Samuelson's fundamental interpretive line that Sraffa's Standard commodity has something to do with Ricardo's search for an 'invariable measure of value'. He argues that one of the fundamental goals of Ricardo's theory was to prove Adam Smith's 'additive theory of value' wrong. For this purpose he needed to prove that a rise in wages would necessarily lead to a fall in the rate of profits. According to Garegnani, Ricardo tried to establish this proposition in a two-step manner. First, he assumed labour theory of value, which ensured that a rise in wages would have no impact on prices and thus on the value of the net output as well as the value of capital. This ensures that if the share of wages in the total net output rises, then this must lead to a fall in the general rate of profits. After this, Ricardo tried to work out the effect on prices of this change in the general rate of profits. But this second step could nullify the first result. To overcome this problem Ricardo tried to find an 'average commodity' or an 'invariable measure of value' that would ensure, if the prices and wages were measured in this numéraire, that the size of the net output remains constant when prices change from labour-values to 'prices of production'. And it is this problem that Sraffa's Standard commodity solves by reducing the $\mathrm{n}$-commodity problem to a onecommodity problem: 'It seems hardly possible to deny that this particular change of coordinates system is a scientific achievement of some magnitude, in that it makes immediately visible a distributive process acting through thousands of intermediate prices' (Garegnani in Kurz, 2013, p. 65).

This reading of Ricardo's problem of the 'invariable measure of value' and the significance of Sraffa's Standard commodity are fraught with significant difficulties (see Sinha, $2010 a$ and b for an alternative interpretation). First of all, Ricardo's two-step price solution, as described by Garegnani, cannot lead to only positive price solutions, some negative price solutions may also arise. Positive profits must be associated with unequal rates of industrial profits in the regime of labour theory of value, if the industries do not have uniform, organic composition of capital. Thus the rise or fall in the rate of profits, that Garegnani refers to, can only be the weighted average rate of profits of the system. Now, if this average rate of profits is imposed on every industry, then some prices must turn out to be negative (it is an implication of the Perron-Forbenius theorem). Let us now take up the relation of the Standard commodity with Ricardo's problem of the 'invariable measure of value' as explained by Garegnani. First of all, it should be clear, and definitely it was clear to Sraffa, that the Standard commodity is not needed to prove the inverse wage-profit relation in a Sraffa-type single-product equation system. It can be proved with any arbitrary numéraire that a rise in wages must lead to a fall in the rate of profits. This is because no price can rise more than wages as a result of a rise in wages - the price of a commodity could rise more than wages only if some of its means of production rose more than wages but this could not apply to the commodity that rose at the highest rate, therefore no price could rise more than wages. Thus Sraffa did not need to invent the Standard commodity to prove Ricardo's simple proposition within a Sraffa-type equation system. Of course, in the case of joint-production, the help of the Standard commodity is needed to prove this proposition, but then Ricardo was not concerned with the joint-production case.

But what about the proposition that Ricardo wanted to prove that a rise in wages would leave the size of the net output constant? The Standard commodity does not prove this proposition. Let's start with a zero rate of profits in both the actual and the Standard system. In this case, the labour theory of value will prevail and the value of the net output of the actual 
system and the Standard system will be equal. Now let's cut the wages to $3 / 4$ of the Standard net product. This divides the Standard net product into $3 / 4$ for the workers and $1 / 4$ for the capitalists. Now if $3 / 4$ of the Standard net product is applied as wages in the actual system, it will generate a different set of prices than the labour-value prices in the actual system, and there is no reason to believe that once $3 / 4$ of the Standard net product is taken as the wage share in the actual system, the remaining net output for profits would be equal to $1 / 4$ of the Standard net product. Actually, Sraffa (1960) is well aware of this:

'But while the share of wages will be equal in value to $3 / 4$ of the Standard national income, it does not follow that the share of profits will be equivalent to the remaining $1 / 4$ of the Standard income' (Sraffa, 1960, p. 23).

So why would Sraffa develop an artefact that does not do the job it was designed for? Actually, in Appendix D of his book, Sraffa makes it quite clear that the construction of the Standard system was integral to his book:

'It should perhaps be stated that it was only when the Standard system and the distinction between basics and non-basics had emerged in the course of the present investigation that the above interpretation of Ricardo's theory suggested itself as a natural consequence' (Sraffa, 1960, p.93).

My perusal of Sraffa's unpublished notes, from the period 1942 to 1944, has convinced me that the discovery of the Standard system and the Standard commodity was intimately related to proving the hypothesis that the ratio of the net output to capital remains constant while the rate of profits moves from zero to its maximum value, and that it was not related to Ricardo's problem. An implication of this discovery was to prove that the relationship of the Standard wages to the average rate of profit of the Standard system must also hold for the actual system as well, irrespective of the actual system being in equilibrium or not. And thus, Sraffa could proclaim that the Standard system shows that '...the rate of profits is a non-price phenomenon' (Sraffa-Papers, D3/12/53, quoted in Sinha, 2010; 2012). Thus, to answer Samuelson's question: the Standard system is an auxiliary to the real or actual system - it helps us discover the mathematical properties of the actual system.

On the question of whether at least one 'basic good' exists in the real world, Samuelson's argument is not very clear. In the case of a single production system, Samuelson claims that 'I believe in a plethora of independent sub-systems that are indecomposable. This denies BASICS' (Samuelson in Kurz, 2013, p. 26). And even if a 'basic good' exists, if its weight in the total economy is very low, then its choice as the index number for price changes would be highly dubious. Further on, in the case of joint-production, Samuelson refers to Manara (1980 [1968]), which argues that, in the general joint-production case, Sraffa's Standard commodity may not exist in the real space.

Garegnani, in response, argues that in Sraffa workers' necessities are 'basics' and, therefore, as long as labour is part of the production process there would be basics in the system. But the fact remains that Sraffa refrains from separating wages into workers' 'necessities' and 'superfluities' - for a good reason. It would be absurd to think that a worker's 'necessity' for potatoes would remain constant even when her consumption of steak is rising (Robinson, 1961). Sraffa, however, correctly suggest that changes in the techniques of production of workers' wage goods would still have impact on all the prices even though workers' wage goods are put in the limbo of non-basics. This is because, as workers' wage goods become cheaper or dearer, the money wages in terms of the Standard commodity 
would be accordingly adjusted, which will change the rate of profits and, therefore, all the prices in the system. But this does not mean that wages are basics in the sense that wage goods could be used to construct the Standard commodity. Garegnani further argues that:

\begin{abstract}
'Also more generally, it seems inevitable to note that if we were to ignore the "basic" role of workers necessaries, and we were prepared to go along with Samuelson's present scepticism about other sources of basics, yet an inexistence of the latter would importantly affect the properties of the system (e.g. on the existence of a maximum rate of profits) and the reference to basic products-whether present or absent in any particular economy-could hardly be avoided in a satisfactory analysis of it' (Garegnani in Kurz, 2013 p. 66).
\end{abstract}

Now, as far as the existence of 'a maximum rate of profits' is concerned, Garegnani's above contention seems to be incorrect. One does not need the existence of a basic good to show that a maximum rate of profits must exist. Its existence depends on the fact that production requires some produced means of production. In other words, capital can never be completely reduced to only 'variable capital', to use Marx's terminology. But the existence of constant capital, as such, in the production process does not mean that it must be a 'basic' good.

It, however, appears to me that Samuelson's contention that there is perhaps no basic good in the real world, is too far-fetched. It would be hard to imagine that if we take the production equation of any good produced today and carry it backward far enough, we wouldn't find some oil or coal or iron or other building materials, etc. anywhere down the chain. Thus Garegnani correctly reminds Samuelson that in 1958 (Dorfman, Samuelson and Solow, 1958) Samuelson himself thought that a large part of national income was made up of basic goods (Garegnani in Kurz, 2013, pp. 66-67).

On the case of joint-production, however, Garegnani remains silent. This is because Sraffians had accepted Manara's critique in the general case of joint-production. Dupertuis and Sinha (2009) have, however, shown that this state of affairs existed because Sraffa's system was assumed to be in equilibrium. Once this unreasonable condition is lifted from Sraffa's equations then the Manara critique can be answered. So there is no need to give in to Samuelson on this point either.

\title{
4. On the Role of Demand on Prices
}

On point (iii) - the limitations of land and capital are underplayed in his theory - Samuelson has two arguments. One is a long-standing one, that when demand shifts from manufacturing to agricultural commodities, the diminishing returns on land would bite and rent would rise and prices of all commodities would be affected (Samuelson, 1978). The second argument is that the assumption of steady state, which, in his opinion, underlies the Sraffian equations, is not a state usually found in reality. When demand shifts from consumption to capital goods, e.g., a developing country deciding to increase future consumption at the cost of current, then the economy's trajectory will no longer be on the steady-state trajectory and, in this case, the own rates of interest of different commodities would differ and therefore the input prices in Sraffa's equations will not be equal to the output prices.

Since the first point is not explicitly made (though implied in his 'conclusion') Garegnani remains silent on this. On my reading of Sraffa, he would not deny the possibility 
of changes in prices due to changes in demand, if those changes in demand cause quantities produced to change. As a matter of fact, Sraffa explicitly denied ever making the argument that in his theory of price determination 'demand' plays only a passive role. In a letter to Arun Bose written in 1964, Sraffa wrote:

'I am sorry to have kept your MS so long-and with so little result.

The fact is that your opening sentence is for me an obstacle which I am unable to get over. You write: "It is a basic proposition of the Sraffa theory that prices are determined exclusively by the physical requirements of production and the social wage-profit division with consumers demand playing a purely passive role." Never have I said this: certainly not in the two places to which you refer in your note 2. Nothing, in my view, could be more suicidal than to make such a statement. You are asking me to put my head on the block so that the first fool who comes along can cut it off neatly.

Whatever you do, please do not represent me as saying such a thing' (Sraffa-Papers, C32, quoted in Sinha, 2007)

Bose's mistake was to assume that Sraffa's outputs were necessarily classical equilibrium outputs, and thus, as in classical gravitation process (see Ricardo, 1951 [1821], p.91), changes in demand patterns would only change the composition of equilibrium outputs but not their prices. It is clear to Sraffa that such a position implies the assumption of constant returns to scale or linear techniques - an attribution of that to his theory, he thinks, would amount to asking him to put his head on the block so that the first fool who comes along can cut it off neatly. Sraffa's position seems to be clear. At any moment, prices are determined by the empirical input-output data with the additional knowledge of 'money wages' in terms of the Standard commodity, irrespective of demand considerations. If, however, changes in demand patterns affect changes in outputs that change the equations, then prices would change - but those prices can again be determined by the given input-output data along with the knowledge of the 'money wages' at that moment.

On the second point of Samuelson, Garegnani's response is that the classical longterm equilibrium, which he attributes to Sraffa, is not the same as the steady- or stationarystate equilibrium. As explained above, Garegnani claims that steady- or stationary-state equilibrium does not allow any movement or adjustment of empirical quantities, whereas the long-period equilibrium allows the empirical outputs to adjust around it - it only claims that the equilibrium point generates a persistent force of attraction for empirical quantities to move towards it. But this does not answer Samuelson's charge. Samuelson's point is that when demand conditions shift, then the outputs of an economy must also move, and during this dynamic process the economy cannot follow 'steady state', which gives rise to unequal 'own rates of interest' across industries and, therefore, the prices of inputs cannot be taken as equal to prices of outputs in Sraffa's equations. Garegnani's answer to this is that it is not possible to analyse a system in motion - all one can do is a comparative-static analysis of a system based on long-period equilibrium:

'But for Sraffa, as well as for all neoclassical theorists up to the Pigous, Robertsons or Champernownes-up, that is, to what I have got used to calling the "Hicksian divide" in neoclassical theory, when, three or four decades ago, the new notions of equilibrium became dominant-there was no question of reproducing the "paths that economic systems [...] do follow". As again, Marshall had pointed out long before, and the predecessors of 
Hicks (1939), including Hicks (1932) himself, had in effect unanimously accepted: "dynamical solution in the physical sense of economic problems are unobtainable [so that] statical solutions afford starting points for such rude and imperfect approaches to dynamical solutions as we may be able to attain to" (Marshall 1898: 39). Normal positions and their comparison over time approved accordingly to be the essential constituents of such attainable "imperfect approaches"' (Garegnani in Kurz, 2013, p. 81).

Leaving aside the question of whether a dynamical system can be analysed or not, the fact of the matter remains that the 'own rates of interests' of the inter-temporal general equilibrium (GE) analysis are not directly translatable into Sraffa's industrial rates of profits. As I have shown in Sinha (2010a; and also Sinha and Dupertuis, 2009b) the translation of the intertemporal GE equations into Sraffa's industrial equations is possible only on the assumption that the commodities' 'own rates of interests' are equal. There cannot be any possibility of prices of inputs being different from prices of outputs in Sraffa's equations. This can be checked by looking at Sraffa's Standard system. The global or the average rate of profits of the Standard system is determined by the physical input-output data without any knowledge of prices. Thus, it is a physical property of the system. Now, as long as prices of the inputs and outputs are taken to be the same, no matter what prices one ascribes to these equations, the value rate of profits would conform to the physical rate. However, if the input prices are taken to be different from the output prices, then the value of the rate of profits would not conform to its physical rate and hence contradict the physical property of the system.

Since Sraffa's system is an ex-post description of an economy, at any moment on its dynamic path the system can be represented by Sraffa's equations with the rate of profits being uniform. As a matter of fact, Sraffa states that:

'It can be said that in any actual economic system there is embedded a miniature Standard system which can be brought to light by chipping off the unwanted parts. (This applies as much to a system which is not in a selfreplacing state as to one which is)' (Sraffa, 1960, p. 20).

Now, from his unpublished notes we have learnt that 'a system which is not in self-replacing state' refers to a dynamic system where some industries may be shrinking due to technical changes - such as industries producing those machines or raw materials that are exclusively used by old and dying out techniques. In such situations one cannot discover 'surplus output' in physical terms since all inputs cannot be deducted from outputs item-by-item, as some outputs would be found to be in lesser quantity than their use as inputs in the system. Sraffa maintained that all real systems are such, and claims that his analysis applies to such systems as well. Thus it would be incorrect to interpret Sraffa's system to be in 'equilibrium' or to argue from a Sraffian perspective, as Garegnani does, that an economic analysis is possible only for equilibrium conditions.

\section{The Last Round}

The last round of the debate between Samuelson (2007) and Garegnani (2007b) shows that these two highly sophisticated minds have been talking past each other. Samuelson's response completely ignores Garegnani's comments and goes on to mathematically work out an inter-temporal general equilibrium master model, which is capable of translating all kinds of 
models, including Sraffa's model, into a GE model, and shows that Sraffa-type systems also require the constant returns assumption and, in the presence of substitution possibilities, a demand shift would affect both distribution and prices in his system as well - of course, Samuelson's GE model takes total factor endowments as given and assumes full employment of all the factors as a condition for the solutions of his equations.

On the question of 'full employment', it should be noted that there is not one word spoken about it in Sraffa's book. As I have suggested above, Sraffa's equations are ex-post descriptions of an economic system after the harvest. All it tells us is how much of the total homogeneous labour-time was employed and the amount of produced means of production were used (we leave aside the complication of land) during the last production cycle. Since it takes either wages or the rate of profits given from outside, it has nothing to say on whether those wages could be associated with unemployed labour or not. Any statement of that sort would require a separate theory of either wages or the rate of profits. Samuelson's position is that distribution must be determined simultaneously with prices as in the GE model. Now, it is a problem for all Sraffians to either prove that the simultaneous determination of distribution and prices is theoretically flawed, or develop an alternative and more persuasive theory of distribution that separates the determination of distribution from the determination of prices. It is the second option that Garegnani emphasises by pointing to the classical economics as having that alternative.

Garegnani argues that the possibility of long-term unemployment coexisting with positive real wages is a major distinguishing feature of the classical economics in opposition to the neoclassical economics:

'The other issue regards the classical economists' theory of wages, the heart of the analysis and of its structure, as I have contended (Garegnani 2007, section I and II) and textually supported by the numerous well known "puzzles" which Smith and Ricardo's theory of wages raise for modern interpreters (Garegnani 2007, section Vc), or by my criticism of Samuelson's interpretation of chapter XXXI 'On Machinery' of the Principles (Garegnani 2007, section Vd)' (Garegnani in Kurz, 2013, p. 126).

Garegnani, in my opinion, stakes too much on Ricardo's 'Machinery' chapter, where Ricardo shows that introduction of machinery would throw out some previously employed workers:

'The discovery and use of machinery may be attended with a diminution of gross produce; and whenever that is the case, it will be injurious to the labouring class, as some of their number will be thrown out of employment, and population will become redundant, compared to the funds that are to employ them' (Ricardo, 1951, p. 390, quoted by Garegnani in Kurz, 2013, p. 78).

One should, however, not forget that Ricardo's problem of introduction of machinery takes place in a dynamic context:

'With every increase of capital and population, food will generally rise, on account of its being more difficult to produce. The consequence of a rise of food will be a rise of wages, and every rise of wages will have a tendency to determine the saved capital in a greater proportion than before to the employment of machinery. Machinery and labour are in constant competition, 
and the former can frequently not be employed until labour rises. ... The demand for labour will continue to increase with an increase of capital, but not in proportion to its increase; the ratio will necessarily be a diminishing ratio' (Ricardo, 1951 [1821], p. 395).

Hence the introduction of machinery is mainly a problem of substitution between labour and machinery in the context of accumulation. Ricardo's position is that machinery is generally introduced to combat rising wages due to rising demand for labour. Introduction of machinery dampens the rise in demand for labour, but does not make it negative. As a matter of fact, Ricardo did not subscribe to Barton's claim that, under certain circumstances, such a tendency to replace labour with machines might be so strong that accumulation would lead to no increase in the demand for labour: 'It is not easy, I think, to conceive that under any circumstances, an increase in capital should not be followed by an increased demand for labour; the most that can be said is, that the demand will be in a diminishing ratio' (Ricardo, 1951 [1821], p. 396 f.n). This explains the last qualifier in Ricardo's quotation cited by Garegnani: 'compared to the funds that are to employ them', i.e., labour will be thrown out in terms of per unit of total fund employed - but as the total fund itself is growing, the total labour employment would also be growing rather than declining. It should also be kept in mind that Ricardo abstracts from the 'rising productivity' or 'technological improvement' aspects of machinery. In the case of rising productivity due to technological change, the rate of profits would rise leading to a rising rate of accumulation and, consequently, rising wages. This would contradict Ricardo's position that the system has a secular tendency to move towards the stationary state.

Both Adam Smith and Ricardo develop their theories of wages in a dynamic context where population mechanism plays a crucial role, which brings into play the forces of demand for and supply of labour in the determination of wages (see Sinha, 2010 for my interpretation and also Hicks and Hollander, 1977). Garegnani ignores the role of population dynamics in the classical theory of wages and, therefore, I remain unconvinced of his interpretation. One way of relating the 'given wage' notion in the classical theory of price determination, would be to separate the dynamic and static contexts. Wages are determined in a dynamic context, whereas the natural prices are determined in the static context. Thus wages can be taken as given at any moment for the static equations of price determination. If this is acceptable, then the time involved in the classical gravitation mechanism must be understood as 'logical time' and not 'historical time'. But, in that case, Garegnani's gambit of using 'statistical average of past several years' as the centre of gravitation outputs, would lose theoretical support.

\section{Concluding Remark}

It seems to me that though Garegnani had a better intuitive understanding of Sraffa's overall project than Samuelson, he unfortunately tried to build his castle on sand. It was not for nothing that Sraffa, in the very opening sentences of his 'Preface,' had warned his reader not to bring the baggage of equilibrium to his book and had drawn the logical connection between the idea of equilibrium and the assumption of constant returns. Garegnani, instead of solving the puzzle of 'uniform rate of profits' in Sraffa's equations, took the easy way out by assuming classical equilibrium for Sraffa's equations. But then there was no logical way out of the assumption of constant returns. Now, as we have seen above, Garegnani had correctly interpreted classical theory of prices in his Ph.D. dissertation when he acknowledged that 'Smith and Ricardo's theory of price is founded on the assumption of constant returns to scale 
...' (Garegnani, 1959, p. 29, f.n. 2). Apparently, it was Sraffa's (1960) statement in the 'Preface', where Sraffa relates his 'standpoint' to that of the old classical economists from Adam Smith to Ricardo without any further elaboration, that led Garegnani to change his mind and attribute 'equilibrium' to Sraffa (1960) and no assumption of constant returns to classical economics to bring the two in line with each other. This created a contradiction at the heart of his interpretation of both Sraffa (1960) and classical economics and tied him up in knots. And this is where Samuelson, in my opinion, was able to checkmate him. But this was no checkmate to Sraffa, as Sraffa did not assume either equilibrium or constant returns.

\section{Acknowledgements}

I thank the Institute of New Economic Thinking (INET) and the Centre for International Governance Innovation (CIGI) for a research grant to support my research on Sraffa. My thanks are also due to Professor John Eatwell, literary executor of Sraffa's unpublished papers, for allowing me to quote from Sraffa-papers and also to the very friendly and helpful staff of the Wren library at Trinity College, University of Cambridge, where Sraffa-papers are housed. I would also like to thank, without implicating, Professors Geoffrey Harcourt and Samuel Hollander for their comments on the earlier draft of this paper and to the two referees of this journal, Andrés Lazzarini and Nuno Ornelas Martins for their comments.

\section{References}

Dorfman, R., Samuelson, P. and Solow, R. (1958) Linear Programming and Economic Analysis, New York: McGraw Hill.

Dupertuis, M.-S and Sinha, A. (2009) 'Existence of the Standard system in the multiple production case: A solution to the Manara problem', Metroeconomica, 60(3), 2009, pp. 432454.

Garegnani, P. (1959) A Problem In The Theory Of Distribution From Ricardo To Wicksell, Ph.D. Disseration, Univerisity of Cambridge.

Garegnani, P. (1984) 'Value and Distribution in the Classical Economists and Marx'. Oxford Economic Papers, 36, pp. 291-325.

Garegnani, P. (1987) 'Surplus Approach to Value and Distribution' in Eatwell, J., Milgate, M. and Newman, P., eds, The New Palgrave. A Dictionary of Economics, Vol. 4, pp. 560-74. London: Macmillan.

Garegnani, P. (1990a) 'Sraffa: Classical versus Marginalist Analysis', in Bharadwaj, K. and Schefold, B., eds, Essays on Piero Sraffa critical perspectives on the revival of classical theory. Delhi: Oxford University Press.

Garegnani, P. (1990b) 'Comment', in Bharadwaj, K. and Schefold, B., eds, Essays on Piero Sraffa critical perspectives on the revival of classical theory, Delhi: Oxford University Press.

Garegnani, P. (2007a) 'Professor Samuelson on Sraffa and the Classical Economics', The European Journal of the History of Economic Thought, 14(2), pp. 181-242.

Garegnani, P. (2007b) 'Samuelson's misses: a rejoinder', The European Journal of the History of Economic Thought, 14(3), pp. 573-85.

Garegnani, P. (2012) 'On the present state of the capital controversy', Cambridge Journal of Economics, 36(6), pp. 1417-32. 
Hahn, F. (1975) 'Revival of Political Economy: The wrong issues and the wrong arguments', Economic Record (51) pp 360-4.

Hahn, F. (1982) 'The neo-Ricardians', Cambridge Journal of Economics, 6, pp. 353-374.

Harcourt, G.C. (1969) 'Some Cambridge Controversies in the Theory of Capital', Journal of Economic Literature, 7, pp. 369-405.

Harrod, R.F. (1961) 'Review of Production of Commodities by Means of Commodites. Prelude to a critique of economic theory', The Economic Journal, LXXI, pp. 783-787.

Hicks, J. and Hollander, S. (1977) 'Mr. Ricardo and the Moderns', Quarterly Journal of Economics, 91, pp. 351-69.

Kurz, H.D (ed.) (2013) The Theory of Value and Distribution in Economics Discussions between Pierangelo Garegnani and Paul Samuelson, London: Routledge.

Manara, C.F. (1980 [1968]) 'Sraffa's Model for the Joint-production of Commodities by Means of Commodities', in Pasinetti, L.L. ed., Essays on the Theory of Joint Production, London: Macmillan.

Ricardo, D. (1951[1821]) On The Principles Of Political Economy And Taxation, $3^{\text {rd }}$ edition, Cambridge: Cambridge University Press.

Robinson, J. (1961) 'Prelude to a Critique of Economic Theory', Oxford Economic Papers, 13, pp. 53-8.

Samuelson, P. (1978) 'The Canonical Classical Model of Political Economy', Journal of Economic Literature, 16, pp. 1415-34.

Samuelson, P. (2000) 'Sraffa's Hits and Misses', in H.D. Kurz (ed.), Critical Essays on Piero Sraffa's Legacy in Economics, Cambridge: Cambridge University Press.

Samuelson, P. (2007) 'Classical and Neoclassical harmonies and dissonances', European Journal of the History of Economic Thought, 14(2), pp. 243-71.

Sinha, A. (2007) 'Sraffa and the Assumption of Constant Returns to Scale: A Critique of Samuelson and Etula', Contributions to Political Economy, 26, pp. 61-70.

Sinha, A. (2010a) Theories of Value from Adam Smith to Piero Sraffa, London: Routledge.

Sinha, A. (2010b) 'A Note on Ricardo's Invariable Measure of Value', Cahiers d'économie politique, $\mathrm{N}^{\circ} 58$, pp. 133-144.

Sinha, A. (2010c) 'In Defence of Adam Smith's Theory of Value', European Journal of the History of Economic Thought, 17(1), pp. 29-48.

Sinha, A. (2012) 'Listen to Sraffa's Silences: A New Interpretation of Sraffa's Production of Commodities', Cambridge Journal of Economics, 36(6), pp. 1323-1339.

Sinha, A. (2013) 'On the Notion of Equilibrium and the Gravitation Mechanism' in Harcourt, G.C. and Kriesler, P. eds, The Oxford Handbook of Post-Keynesian Economics vol.1, New York: Oxford University Press, pp. 101-122.

Sinha, A. (2014) 'A New Perspective on Sraffa', in Bellofiore, R. and Carter, S. eds, Towards a New Understanding of Sraffa, New York: Palgrave Macmillan, pp. 81-93.

Sinha, A and Dupertuis, M.-S. ( 2009a) 'Sraffa's System: Equal Rate of Profits and the Notion of Centre of Gravitation', Journal of Economic Behavior and Organization, 71, pp. 495-501.

Sinha, A. and Dupertuis, M.-S. (2009b) 'Sraffa and the Question of Equilibrium', Cahiers d'économie politique, 2009, $\mathrm{N}^{\circ}$ 56, pp. 91-100.

Smith, A. (1981[1776]) An Inquiry Into The Nature And Causes Of The Wealth Of Nations Volume I, Indianapolis: Library Fund. 
Sraffa, P. (1951) 'Introduction', Works and Correspondence of David Ricardo vol. I, Cambridge: Cambridge University Press.

Sraffa, P. (1960) Production of Commodities by Means of Commodities, Cambridge: Cambridge University Press.

Sraffa, P. ND. Sraffa Papers. Wren Library, Trinity College, Cambridge.

'Symposium 1966 on reswitching of methods' in Quarterly Journal of Economics, 81.

\section{SUGGESTED CITATION:}

Sinha, A. (2015) 'A Reflection on the Samuelson-Garegnani Debate.' Economic Thought, 4.2, pp. 48-67. http://www.worldeconomicsassociation.org/files/journals/economicthought/WEA-ET-4-2-Sinha.pdf 